\title{
ANALISIS PENDAPATAN PETANI KARET DI KECAMATAN INDRALAYA UTARA KABUPATEN OGAN ILIR PROVINSI SUMATERA SELATAN
}

\author{
(Analysis of Rubber Farmers' Income in North Indralaya District, Ogan Ilir Regency, \\ South Sumatra Province) \\ Taufik Syamsuddin*) ${ }^{*}$ ) \\ 1)Dosen Fakultas Pertanian Universitas Tamansiswa Palembang \\ *)Penulis untuk korespondensi: syamsuddintaufik@gmail.com
}

\begin{abstract}
ABSTRAK
Analisis Pendapatan Petani Karet di Kecamatan Indralaya Utara Kabupaten Ogan llir Provinsi Sumatera Selatan. Penelitian ini bertujuan untuk mengetahui pendapatan petani karet yang ada di Kecamatan Indralaya Utara Kabupaten Ogan llir. Data yang diperoleh dari hasil kuisioner atau wawancara langsung dengan petani karet yang ada di Kecamatan Indralaya Utara. Produksi karet yang diperoleh oleh petani karet di Kecamatan Indralaya Utara Kabupaten Ogan Ilir ada memperoleh produksi tinggi, dan ada yang memperoleh produksi rendah walaupun dengan harga tetap 15 ribu/kg. Biaya yang dikeluarkan oleh petani karet di Kecamatan Indralaya Utara Kabupaten Ogan llir pada tahun 2016. Untuk luas lahan karet 1 ha petani karet mengeluarkan biaya sebesar Rp. 1.700 .000 dalam setahun. dan untuk luas lahan petani karet mengeluarkan biaya sebesar Rp. 2.400.000. Pendapatan yang diperoleh petani karet di Kecamatan Indralaya Utara Kabupaten Ogan llir yang luas lahan 1 ha memperoleh pendapatan sebesar Rp. 32.400 .000 sampai Rp. 43.200.000 dalam satu tahun. dan yang luas lahan 2 ha memperoleh pendapatan sebesar Rp. 64.800.000-86.400.000 dalam satu tahun.
\end{abstract}

Kata kunci: karet, pendapatan, Ogan Ilir

\section{ABSTRACT}

Analysis of Rubber Farmers' Income in North Indralaya District, Ogan llir Regency, South Sumatra Province. This study aims to determine the income of rubber farmers in North Indralaya District, Ogan llir Regency. Data obtained from the results of questionnaires or direct interviews with rubber farmers in the District of North Indralaya. Rubber production obtained by rubber farmers in the District of North Indralaya, Ogan llir District, there is a high production, and there is a low production, although with a fixed price of 15 thousand / kg. Costs incurred by rubber farmers in the North Indralaya District of Ogan Ilir Regency in 2016. For an area of 1 ha of rubber land rubber farmers incurred a cost of Rp. 1.700 .000 in a year. and for the size of land the rubber farmers spent Rp. 2.400.000. The income obtained by rubber farmers in the District of North Indralaya, Ogan llir Regency, which has an area of 1 ha, earns an income of Rp. 32.400 .000 to Rp. 43.200 .000 in one year. and those with 2 hectares of land receive income of Rp. $64.800 .000-86.400 .000$ in one year.

Keywords: karet, income, Ogan llir

\section{PENDAHULUAN}

Tanaman karet merupakan salah satu komoditi perkebunan yang menduduki posisi cukup penting sebagai sumber devisa nonmigas bagi Indonesia, sehingga memiliki prospek yang cerah, oleh sebab itu upaya peningkatan produktifitas usahatani karet terus dilakukan terutama dalam bidang teknologi 
budidaya. Perkebunan karet Indonesia dinilai strategis karena pada tahun 2005 mempunyai areal terluas di dunia yaitu 3,262 juta ha,volume ekspor karet Indonesia sebesar 1,874 juta ton merupakan salah satu sumber devisa kedua setelah kelapa sawit dengan nilai US \$2,18 juta, dan merupakan sumber pendapatan bagi lebih dari 15 juta penduduk Indonesia (Direktorat Jenderal Bina Produksi Perkebunan, 2010).

Pola kebijakan dan strategi agribisnis karet Indonesia yaitu mensejahterakan masyarakat dan berkelanjutan yang berbasis lateks dan kayu berdaya saing tinggi dengan strategi peningkatan produktivitas perkebunan rakyat melalui penggunaan klon unggul, percepatan peremajaan karet tua atau rusak, diversifikasi usahatani dan penerapan pola tanam sela (Departemen Pertanian Republik Indonesia, 2005). Rendahnya produktivitas karet rakyat menyebabkan rendahnya produksi karet dan pendapatan dari usaha tani karet juga mempengaruhi rendahnya pendapatan rumah tangga petani sedangkan kebutuhan hidup petani tetap bahkan meningkat sehingga mendorong petani meningkatkan pendapatannya dengan melakukan eksploitasi penyadapan kurang baik dan berlebihan yang menyebabkan tanaman karet menjadi rusak.

Petani karet merupakan salah satu kelompok masyarakat yang mempunyai corak kehidupan yang berbeda dari masyarakat lainnya. Demikian juga kehidupan masyarakat petani karet di Kecamatan Inderalaya Utara Kabupaten Ogan Ilir. Masalah yang mendasar dalam kehidupan petani karet di Kecamatan Inderalaya Utara adalah kemiskinan. Kemiskinan ini di sebabkan oleh berbagai faktor, baik internal maupun eksternal. Salah satu faktor eksternal yang sangat penting adalah sistem pemasaran hasil karet yang lebih menguntungkan pedagang perantara.

Produksi karet di Provinsi Sumatera
Selatan pada tahun 2015 sebesar 51.377 ton/tahun ini sangat menunjang Pendapatan petani karet, dengan luas tanam sebesar 96.470 hektar tersebar dibeberapa kabupaten yang ada di Provinsi Sumatera Selatan. (Sumatera Selatan Dalam Angka Badan Pusat Statistik Provinsi Sumatera Selatan tahun 2015). Melonjak harga karet dan membuat banyak masyarakat yang mengusahakan tanaman ini sehingga luas arealnya terus bertambah setiap tahunnya. Pada Tahun 2016 luas kebun karet yang ada di Kabupaten Ogan Ilir mencapai 24.096 hektar. Dengan luas lahan tersebut dihasilkan produksi karet sebesar 17.270 ton. Kabupaten Ogan Ilir salah satu Kabupaten yang ada di Provinsi Sumatera Selatan mendapat bantuan membuka 9500 hektar kebun karet sebagai upaya percepatan peningkatan ekonomi rakyat, pada tahun 2016 jumlah petani bertambah banyak dari tahun 2015, karena setelah begitu menjanjikan petani lain ikut terangsang dan mengajukan permohonan membuka kebun karet rakyat dengan bantuan pemerintah. Program perkembangan kebun rakyat ini juga merupakan langkah pemerintah daerah menyahuti permintaan investor Negara Thailand mengharapkan Kabupaten Ogan Ilir menjadi sentra pemasaran karet dengan target produksi berskala besar ekspor. Selain membantu percepatan peningkatan ekonomi rakyat program rehabilitas lahan tidur menjadi kebun karet ikut mendorong terlaksananya program pemerintah daerah mengembangkan komoditas kompetensi inti wilayah ini. Berikut ini luas area karet yang ada di Kecamatan Inderalaya Utara Kabupaten Ogan llir.

Tabel 1. Luas Area dan Produksi Karet di Kecamatan Indralaya Utara Kabupaten Ogan llir Tahun 20102013.

\begin{tabular}{|l|l|l|l|}
\hline No & Tahun & Luas $(\mathrm{Ha})$ & Produksi (Ton) \\
\hline 1 & 2013 & $2.071,00$ & $1.799,80$ \\
\hline
\end{tabular}




\begin{tabular}{|l|l|l|l|}
\hline 2 & 2014 & $2.196,00$ & $1.799,80$ \\
3 & 2015 & $2.170,06$ & $1.981,00$ \\
4 & 2016 & $2.268,06$ & $2.519,87$ \\
\hline
\end{tabular}

Sumber: Badan Pusat Statistik Kabupaten Ogan Ilir, 2013

Berdasarkan tabel 1 diatas dapat kita lihat luas areal karet di Kecamatan Indralaya Utara Kabupaten Ogan Ilir pada tahun 2013 dengan luas 2071,00 ha, dengan produksi karet pada tahun tersebut sebesar 1799,80 ton, pada tahun 2014 luas area seluas 2196,00 ha, pada tahun luas lahan bertambah. dan produksi belum mengalami peningkatan masih seperti tahun sebelumnya sebesar 1799,80 ton, dan pada tahun 2015 luas areal karet bertambah sebesar 2170,06 ha, dengan produksi karet sebesar 1981,00 ton, pada tahun tersebut produksi semakin bertambah kerena semakin banyak bertambah batang karet yang sudah diambil getahnya, dan pada tahun 2016 luas areal karet 2268,06 ha, semakin luas dari dan produksi sebesar 2519,87 ton.

Berdasarkan penjelasan diatas dapat kita lihat luas areal karet yang ada di Kecamatan Inderalaya Utara Kabupaten Ogan llir semakin luas dan produksinya juga semakin meningkat ini dikarenakan semakin adanya perhatian dari pemerintah memberi bantuan bibit kepada masyarakat yang mempunyai lahan untuk ditanami pohon karet, sehingga sangat membantu perekonomian masyarakat tersebut dalam memenuhi kebutuhan sehari hari.

\section{RumusanMasalah}

Adapun permasalahan yang akan dibahas dalam tulisan ini adalah menganalisis bagaimana pendapatan petani karet di Kecamatan Indralaya Utara Kabupaten Ogan llir.

\section{TujuanPenelitian}

Tujuan penelitian ini adalah untuk mengetahui pendapatan petani karet yang ada di Kecamatan Indralaya Utara Kabupaten Ogan llir.

\section{METODEPENELITIAN}

\section{Populasi danSampel}

Populasi yang diambil oleh penulis di daerah penelitian sangat luas aspek analisisnya yaitu pendapatan petani karet di Kecamatan Indralaya Utara Kabupaten Ogan Ilir. Namun karena aspek penelitian sangat luas penulis mengambil sampel hanya 3 desa. yaitu. Desa Parit, desa Bakung, dan desa Payakabung. Sampel merupakan sebagian dari seluruh objek penelitian yang diambil yang mewakili seluruh populasi. Sampel yang diambil sebanyak 75 orang petani karet di Kecamatan Indralaya Utara Kabupaten Ogan llir.

Teknik pengambilan sampel dalam penelitian ini menggunakan boring sampling (Secara acak sederhana), karena objek terlalu luas. Hal ini dilakukan karena keterbatasan waktu penelitian.

\section{Metode PengumpulanData}

Data yang diperoleh dalam penelitian ini terdiri dari data primer dan data sekunder. Data primer diperoleh dari wawancara langsung dengan petani karet di Kecamatan Indralaya Utara dengan menggunakan kuisioner yang telah disiapkan. Sedangkan data sekunder merupakan data pelengkap yang diperoleh dari berbagai instansi yang berhubungan seperi BPS, Dinas Pertanian dan literatur yang mendukung penelitian ini..Teknik pengumpulan data yang digunakan dalam penelitian ini adalah:

a. Observasi merupakan salah satu teknik operasional pengumpulan data melalui proses pencatatan secara cermat dan sistematis terhadap obyek yang diamati 
secara langsung. Dalam metode ini pihak pengamat melakukan pengamatan dan pengukuran dengan teliti terhadap obyek yang diamati, bagaimanakah keadaannya, kemudian dicatat secara cermat dan sistematis peristiwa-peristiwa yang diamati, sehingga data yang telah diperoleh tidak luput dari pengamatan.

b. Wawancara merupakan metode pengumpulan data dengan bertanya langsung. Dalam wawancara ini terjadi interaksi komunikasi antara pihak peneliti selaku penanya dan responden selaku pihak yang diharapkan memberikanjawaban.

c. Kuisioner merupakan suatu teknik pengumpulan data yang dilakukan dengan cara menyebarkan daftar pertanyaan kepada responden yang telah disusun secara sistematis dan sesuai dengan rencana jawaban yangdiperlukan.

\section{Model Analisis Data}

Pendapatan Usahatani dapat dihitung dengan rumus : ( Soekartiwi, 2002.)

\section{$\mathrm{Pd}=\mathrm{TR}-\mathrm{TC}$}

dimana :

$\mathrm{Pd}=$ Pendapatan Usahatani

$T R=$ Total Penerimaan (Total Revuneu)

$T C=$ Total biaya $($ total cost $)$

\section{HASIL DAN PEMBAHASAN}

\section{Gambaran Umum Tanaman karet di Kecamatan Indralaya Utara.}

Perkebunan karet Adalah salah satu mata pencarian utama masyarakat Kecamatan Indralaya Utara Kabupaten Ogan llir adapun status kepemilikan lahan adalah lahan milik sendiri, dalam melaksanakan kegiatan usaha taninya pembukaan lahan, persiapan bibit dan penanaman semuanya dikelola sendiri. Persiapan bibit dan penanaman karet telah menghasilkan dengan jangka waktu 5 tahun.
Petani karet di Kecamatan Indralaya Utara Kabupaten Ogan llir melakukan tahapantahapan sebagai berikut :

\section{PembukaanLahan}

Pada awalnya pembukaan lahan untuk tanaman karet dilakukan dengan penebangan, dalam penebangan ini biasanya dibagi menjadi dua tahap yaitu yang pertama menebang tumbuhan yang masih kecil dan kedua menebang tumbuhan besar dan dilanjutkan dengan pembakaran.

\section{Penanaman.}

Sebelum melakukan penanaman terlebih dahulu menentukan jarak tanaman karet. Adapun jarak penanaman karet di Kecamatan Indralaya Utara $4 \times 6$ meter, sehingga dapat diketahui dalam satu hektar terdapat 416 pohon karet,

\section{Pemupukan}

Pada umumnya pemupukan dilakukan setahun dua kali, pemupukan diberikan untuk mempercepat pertumbuhan, caranya pupuk dimasukkan kedalam lubang 1-1,5 meter dari pohon pada lahan yang tersedia, pupuk yang digunakan adalah pupuk urea, SP36 danKCL.

\section{Pemeliharaan}

a. Penyiangan

Penyiangan dilakukan tergantung pada keadaan tanaman penggangu (gulma). Umumnya penyiangan 2-3 kali setahun.

\section{b. Pengendalian hama dan penyakit}

Pengendalian hama dan penyakit dilakukan apabila gejala serangan mulai tampak, binatang yang sering menganggu pada awal penanaman tanaman karet adalah babi hutan, hal yang ilakukan petani adalah mengusir babi tersebut atau dibuat pembatas. 


\section{Penyadapan}

Penyadapan merupakan salah satu kegiatan dari pengusahaan tanaman karet. Tanaman karet uumnya dapat disadap setelah berumur 5 tahun, penyadapan dilakukan pada pagi hari mulai pukul 06.00 dengan menggunakan pisau sadap. Notasi penyadapan dilakukan petani di Kecamatan Indralaya Utara 2 hari sekali, tetesan lateks ditampung didalam mangkuk sadap, mangkuk sadap yang digunakan didaerah penelitian ini adalah batok kelapa.

\section{BiayaProduksi}

Biaya produksi dalam usaha tani ini mencakupi biaya pupuk, biaya peptisida, dan biaya lain-lain, jumlah biaya produksi dalam satu tahun dengan jumlah 75 responden.

Tabel 2. Biaya yang dikeluarkan oleh Petani karet di Kecamatan Indralaya Utara Kabupaten Ogan llir

\begin{tabular}{|c|c|c|c|}
\hline $\begin{array}{c}\text { Pupuk } \\
\text { (Ribu Rp) }\end{array}$ & $\begin{array}{c}\text { Peptisida } \\
\text { (Ribu Rp) }\end{array}$ & $\begin{array}{c}\text { Lain-Lain } \\
\text { (Ribu Rp) }\end{array}$ & $\begin{array}{c}\text { Jumlah } \\
\text { (Ribu } \\
\text { Rp) }\end{array}$ \\
\hline 800. & 400 & 200. & 1.400 \\
900. & 500 & 200. & 1.600 \\
1.000. & 500 & 200. & 1.700 \\
2.000. & 1000 & 300. & 2.400 \\
\hline
\end{tabular}

Berdasarkan tabel diatas dapat kita lihat biaya yang dikeluarkan oleh petani karet di Kecamatan Indralaya Utara Kabupaten Ogan llir pada tahun 2013. Petani karet yang mengeluarkan biaya produksi sebesar 1.400.000 terdapat 22 petani karet dengan luas lahan 1 ha. dan petani yang mengeluarkan biaya produksi sebesar 1.600 .000 terdapat 31 petani karet dengan luas lahan juga 1 ha. dan petani karet yang mengeluarkan biaya produksi sebesar 1.700 .000 terdapat 19 petani karet juga dengan luas lahan 1 ha. Untuk luas lahan karet 2 ha petani karet mengeluarkan biaya sebesar 2.400.000 terdapat 3 petani karet Biaya yang dikeluarkan untuk membeli pupuk, peptisida dan untuk biaya lain-lain.

\section{Produksi karet di Kecamatan Indralaya Utara Kabupaten Ogan Ilir}

Dalam mengusahakan usahataninya tiap petani memiliki lahan 1 ha, hanya ada sebagian kecil memiliki lahan sampai 2 ha. dengan hasil produksi antara petani yang satu dengan petani yang lainya bervariasi ada yang mendapatkan hasil yang tinggi, dan juga ada yang mendapatkan hasil yangrendah.

Untuk lebih jelas Produksi karet yang ada di Kecamatan Indralaya Utara Kabupaten Ogan Ilir pada tahun 2016 dapat dilihat pada tabel berikut ini :

Tabel 3. Produksi Karet Di Kec.Indralaya Utara Kabupaten ogan Ilir Tahun 2016

\begin{tabular}{|l|l|l|c|}
\hline No & $\begin{array}{r}\text { Luas } \\
\text { (Ha) }\end{array}$ & $\begin{array}{c}\text { Produksi } \\
\text { (Hari) }\end{array}$ & $\begin{array}{c}\text { Jmlh Hari Kerja } \\
\text { (Hari) }\end{array}$ \\
\hline 1 & 1 & 12 & 15 \\
2 & 1 & 13 & 15 \\
3 & 1 & 14 & 15 \\
4 & 1 & 15 & 15 \\
5 & 1 & 16 & 15 \\
6 & 1 & 24 & 15 \\
7 & 2 & 30 & 15 \\
8 & 2 & 32 & 15 \\
\hline
\end{tabular}

Berdasarkan tabel diatas dapat kita lihat bahwa produksi karet di Kecamatan Indralaya Utara Kabupaten Ogan Ilir pada tahun 2016 dengan produksi $12 \mathrm{~kg}$ perhari diperoleh oleh 10 orang petani karet yang ada di Kecamatan Indralaya Utara Kabupaten Ogan Ilir, dan produksi $13 \mathrm{~kg}$ diperoleh oleh 12 orang, dan produksi $14 \mathrm{~kg}$ karet perhari diperoleh oleh 14 orang, produksi $15 \mathrm{~kg}$ diperoleh oleh 17 orang petani karet yang ada di Kecamatan Indralaya Utara dan 19 orang petani karet memperoleh $16 \mathrm{~kg}$ karet, dan yang memperoleh $24 \mathrm{~kg}$ karet diperoleh oleh 1 orang, dan $30 \mathrm{~kg}$ karet diperoleh oleh 1 orang, dan $32 \mathrm{~kg}$ diperoleh oleh 1orang. Berdasarkan penjelasan 
diatas dapat kita lihat produksi karet yang dihasilkan oleh petani karet yang ada di Kecamatan Indralaya Utara sangat bervariasi berkisar antara 12 sampai $32 \mathrm{~kg}$. walaupun dapat kita lihat luas lahan yang dimiliki rata-rata 1 ha, hanya ada beberapa orang yang memiliki lahan 2 ha, dengan produksi yang dihasilkan jugaberbeda.

\section{Pendapatan Petani}

Pendapatan Usahatani karet di Kecamatan Indralaya Utara Kabupaten Ogan llir untuk lebih jelas dapat dilihat ditabel bawah ini.

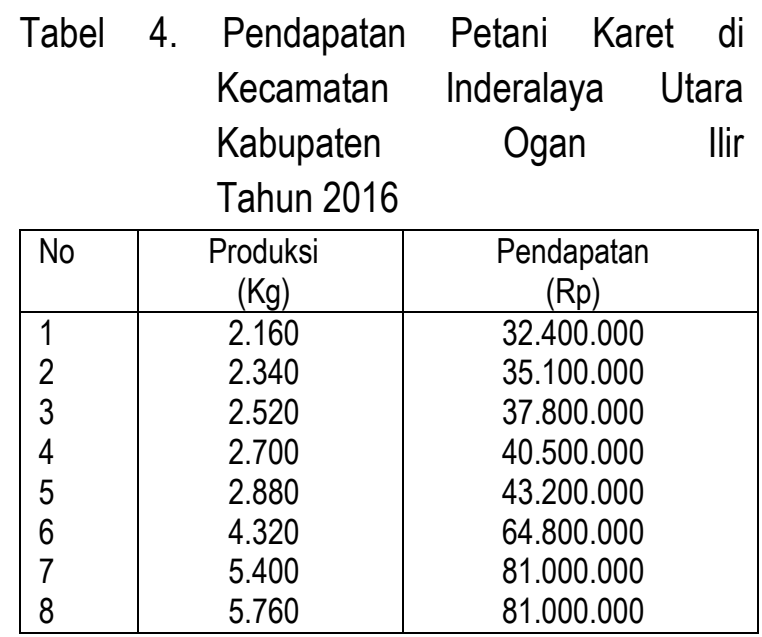

Berdasarkan tabel 4 diatas dapat kita lihat produksi dan pendapatan karet di Kecamatan Indralaya Utara Kabupaten Ogan Ilir pada tahun 2016, produksi karet sebanyak $2.160 \mathrm{~kg}$ pertahun didapatkan dari produksi karet perhari dikalikan dengan hari kerja dan dikalikan dengan 12bulan.

Pendapatan Rp. 32.400 .000 hanya diperoleh oleh 10 orang petani dengan luas lahan satu hektar, dan produksi karet 2340 ton dengan pendapatan Rp.35.100.000 diperoleh oleh 12 orang dengan luas lahan 1 ha, dan produksi karet sebanyak $2.520 \mathrm{~kg}$ dengan pendapatan Rp. 37.800 .000 diperoleh oleh 14 orang dengan luas lahan juga 1 ha, produksi karet $2.700 \mathrm{~kg}$ dengan pendapatan yang diperoleh sebesar Rp. 40.500 .000 diperoleh oleh
17 orang dengan luas lahan 1 ha, dan produksi karet di Kecamatan Indralaya Utara Kabupaten Ogan llir sebanyak $2.880 \mathrm{~kg}$, dengan pendapatan sebesar Rp. 43.200 .000 diperoleh oleh 19orang dengan luas lahan 1 ha, dan produksi $4320 \mathrm{~kg}$, dengan pendapatan Rp. 64.800 .000 , diperoleh oleh 1 orang dengan luas lahan 2 ha, dan produksi $5.400 \mathrm{~kg}$ dengan pendapatan Rp. 81.000.000 diperoleh oleh 1 orang dengan luas lahan 2 ha, produksi $5.760 \mathrm{~kg}$ dengan pendapatan sebesar Rp. 86.400 .000 diperoleh oleh 1 orang, dengan luas lahan 1 ha.

Dari penjelasan diatas dapat kita lihat produksi dan pendapatan petani karet di Kecamatan Indralaya Utara Kabupaten Ogan Ilir yang diperoleh sangat bervariasi produksi yang dihasilkan berkisar $12-15 \mathrm{~kg} / \mathrm{hari}$ walaupun luas lahan yang sama tetapi pendapatannya berbeda, ini dikarenakan produksi karet yang diperoleh oleh petani karet di Kecamatan Indralaya Utara Kabupaten Ogan Ilir ada memperoleh produksi tinggi, dan ada yang memperoleh produksi rendah walaupun dengan harga tetap 15ribu/kg

\section{Kesimpulan}

1. Berdasarkan hasil penelitian dan pembahasan, dan disimpulkan secara komprehensif bahwa pendapatan petani karet pada tahun 2016produksi dan pendapatan petani karet di Kecamatan Indralaya Utara Kabupaten Ogan Ilir yang diperoleh sangat bervariasi produksi yang dihasilkan berkisar 12-15 kg/hari walaupun luas lahan yang sama tetapi pendapatannya berbeda.

2. Produksi karet yang diperoleh oleh petani karet di Kecamatan Indralaya Utara Kabupaten Ogan Ilir ada menghasilkan produksi tinggi, dan ada yang menghasilkan produksi rendah walaupun dengan harga tetap $15 \mathrm{ribu} / \mathrm{kg}$.

3. Biaya yang dikeluarkan oleh petani karet di Kecamatan Indralaya Utara Kabupaten Ogan llir pada tahun 2016. Untuk luas lahan karet 1 ha petani karet mengeluarkan biaya 
sebesar Rp. 1.700 .000 dalam setahun. dan untuk luas lahan 2 ha petani karet mengeluarkan biaya sebesar Rp.2.400.000.

4. Pendapatan yang diperoleh petani karet di Kecamatan Indralaya Utara Kabupaten Ogan llir yang luas lahan 1 ha memperoleh pendapatan sebesar Rp. 32.400 .000 sampai Rp. 43.200.000 dalam satu tahun dan yang luas lahan 2 ha memperoleh pendapatan sebesar Rp. $64.800 .000-\mathrm{Rp}$. 86.400 .000 dalam satu tahun.

\section{Saran}

1. Adapun saran yang dapat dilakukan bagi para petani adalah dapat menjaga kualitas karet tidak menurunkan harga karet. Oleh karena itu petani karet tidak perlu mencampuri karetnya dengan barang yang dapat memberatkan timbangan karet.

2. Sedangkan bagi para pedagang hendaknya tidak berusaha untuk menekan harga beli karet. Jika harga karet terlalu turun drastis dapat berpengaruh pada motivasi petani karet sebagai dampaknya produksi karet akan menurun.

3. Bagi Pemerintah sendiri harusnya selalu menjadi motivator, inspirator dan diperhatikan pemerintah. Hal ini akan berpengaruh pada peningkatan produksi karet petani

\section{DAFTAR PUSTAKA}

Anwar, Chairil. 2006. Perkembangan Pasar dan prospek Agribisnis Karet di Indonesia. Medan.

Badan Pusat Statistik (BPS) 2013. Sumatera Selatan dalam Angka Badan Pusat Statistik (BPS) 2015. Sumatera Selatan dalam Angka.

Daniel, M. 2004. Pengantar Ekonomi Pertanian. Jakarta: PT. Bumi Aksara. Jakarta
Didit, Heru, Setiawan dan Agus Andoko. 2005, Petunjuk Lengkap Budidaya Karet, PT. Agromedia Pustaka. Jakarta.

Direktorat Jenderal Bina Produksi Perkebunan, 2010 Statistik Perkebunan Indonesia komoditas Karet. Jakarta.

Firdaus Muhammad, 2009. Manajemen Agribisnis. Bumi Aksara, Jakarta.

Mankiw, N. Gregory. 2006. Pengantar Ekonomi Makro. Edisi-3. Salemba Empat. Jakarta.

Nasution, Mustafa Edwin. Et. Al. Pengenalan Eklusif Ekonomi. Kencana Prenada Group. Jakarta

Pane, AA, 2011. Prospektif Harga Karet. Peragi. Jakarta.

Priyanto, I. 2013. Efektivitas Pemupukan Tanaman Karet. Gramedia. Jakarta

Rosyidi, Suherman. 2003. Pengantar Teori Ekonomi : Pendekatan Kepada Teori Ekonomi Mikro an Makro. PT. Raja Grafindo Perkasa. Jakarta

Soekartiwi, 2003. Teori Ekonomi Produksi. Rajawali. Jakarta.

Suharno, 2007. Teori Mikro Ekonomi. Percetakan Andi Offset. Jogyakarta.

Sutrisno, 2008. Raja Grafindo. Jakarta.

Sukirno, Sadono. 2008. Teori Pengantar Ekonomi Makro. Edisi ke Tiga. PT. Raja Grafindo Persada. Jakarta.

Sugiarto, Herlambang. 2007. Ekonomi Mikro. PT. Gramedia Pustaka Utama. Jakarta. 